\title{
Trauma and Fluid Identity in Paul Auster's Man in the Dark
}

\author{
C. Jothi
}

Abstract: Literature has influenced the lives of human beings. In the human mind, there is a space for memories, introspection, foreshadow, flashback and awful remembrances that are coloured by pain, wound, and trauma. Psychological trauma is a sort of harm to the mind that happens because of a seriously upsetting occasion. It is much the same as other psychosomatic ideas in medicinal history, for example, stun and stress. It has been exposed to an assortment of translations crosswise over orders since it rose in the nineteenth century as a thought to catch mental encounters and conditions in current society and societies. Psychological traumatic experiences often involve physical trauma that threatens the survival of human beings and the sense of security. Sigmund Freud is an eminent figure in the literary studies of trauma. The connecting of injury hypothesis and artistic content reveals insight into contemporary fiction as well as focuses on the inborn associations between injury hypothesis and the abstract which have been disregarded. Paul Auster, an American writer, blends absurdism, existentialism and crime fiction, and the search for identity and personal meaning. He creates his own postmodern form in his writings. His, Man in the Dark, is a staggering novel about the numerous substances we possess as wars fire surrounding us. By investigating 'Man in the Dark' through Lacanian thought of a divided subjectivity, the injury for Brill is no nostalgic return of the past. It is depicted as the inconceivable experience with the missed reality which is brought about via 'machine' or reiteration. The paper analyses the function of the traumatized protagonist and discusses the influence of place in the reformulation of the self.

Keywords : Fragmented Subjectivity, Introspection,Memories, Psychology, Trauma.

\section{INTRODUCTION}

Trauma has turned into a significant and persuasive worldview for perusing Contemporary American Literature. The Contemporary American trauma accounts offer a convenient and contradicting intercession into discussions about American essayist's delineation of injury and its results. The aim of this paper is to overcome this casual circularity by illuminating the imaginative and embodied aspects of trauma's subjective experience in Paul Auster's novel Man in the Dark. In Trauma: Explorations in Memory, Cathy Caruth says,

Post Traumatic Stress Disorder results from an overwhelming event or events and manifest itself in repeated intrusive hallucinations, dreams, thoughts or behaviour stemming from the event, along with mumbling that may have begun during or after the experience. (4)

The memory of traumatic events cannot be conjured up. Horrible encounters frequently happen at a specific time after

Revised Manuscript Received on December 20, 2019.

C.Jothi*, Department of English, Kalasalingam Academy of Research and Education, Srivilliputtur, India. Email:jothic.phd@gmail.com the occasion. Thus enduring the injury can be more horrible than the experience itself. Awful accidents are generally exceptionally surprising and not completely comprehended. Individuals do not have a clue when it happens. The awful accidents cannot be intentionally verbalized, memory is an extremely testing undertaking. Caruth says,

Traumatized people often feel that something gets lost when they try to relate their experiences. One important reason for this is that trauma when it is translated into speech loses its sense of responsibility. (In Trauma 153-154)

It is very hard to speak with the general population or individual of the damaged. Injury is a demonstration of making a significant account that turns out to be practically inconceivable with respect to awful encounters that are experienced however transmitted starting with one age then onto the next. Sigmund Freud thinks that the injury is adversely associated with an individual's cognizant memory of the occasion. The reiteration of the injuries frequently enables the unfortunate casualty to re- order an aggravating background while accepting a functioning and all the more dominant job in it. Horrendous reiteration incorporates implosion, conduct, and the maltreatment of others and the returning to of the maltreatment in dreams, flashbacks, and dreams. The trouble of imparting horrendous mishaps is met with the powerlessness to tune in to those recollections.

The development of injury in stories and verse enables the speaker to apply full command over his or her awful past. It shapes the traumatic memory of the protagonist. There is no complete remedy for traumatized protagonists who suffer the mental wound and lose their control over their personal present life. The mental wound that comes later as a response to the violent events is incurable and unbearable.

By investigating 'Man in the Dark' through Lacanian thought of a divided subjectivity, the injury for Brill is no nostalgic return of the past. It is depicted as the inconceivable experience with the missed reality which is brought about via 'machine' or reiteration. In this novel Man in the Dark, the protagonist Brill's life is checked and turned by the various profoundly irritating and painful events such as his French wife Sonia's death due to cancer, the loneliness and bereavement of his daughter Miriam after her husband deserts her and the horrific murder of his granddaughter Katya and her boyfriend Titus who has dropped out of film school. He loses his leg in a car accident and he is in a wheelchair and cannot come out from the room and spend time with his family members.

The man holding the head backs away from the camera [...] and a fourth man approaches with a knife. One by one working with great speed and precision stabs out the boy's eyes. The camera rolls for a few more seconds, and then the screen goes back. Impossible to know how long it has lasted. Fifteen minutes. A thousand years. [145] 


\section{Trauma and Fluid Identity in Paul Auster's Man in the Dark}

This novel is found unequivocally in the inventive awareness of a writer, reviewer, and critic. The protagonist Brill does not make a nonexistent story on account of an opportunity he looks to fill yet rather from the press of beset and horrible misfortune that requests his consideration. He does so to divert or escape from the real and painful reality of his own past. The overall point seems to be that every life contains a tragedy of itself and it has to be overcome and lived through. Auster is in the wake of something completely unique in this frequenting and delightfully made work than theoretical fiction. The oppressed world is not Auster's yet rather his focal character's (August Brill), the titular "man in the dark". Brill, a 72-year old retired literary critic, is a profoundly damaged human character who is offering a house to his similarly harmed and edgy little girl and granddaughter.

Brill's battle is not just about his sleep deprivation, or his mishap, or his pain; it is tied in with choosing whether he needs to live beyond words. He lies conscious during the evening creating this ridiculous clash and envisions a puzzled remain in for himself named Owen Brick, a mystical performer who remains unaware of war or legislative issues. From the very beginning of the story, he wakes up into a hole in the middle of a battleground. He is often dragged out by a soldier named Sergeant Serge and dragooned into a role as an assassin, a person who has been considered to be the reason for the war. He insists Brick meet Lou Frisk in Wellington; he wanders in the middle of the road without knowing what to do next. There is no one to help him. He does not know about the war whether it is between North and South or East and West or Red against Blue or White against Black. The novel aims at depicting the mental and physical wounds of the protagonist in order to reveal the truth.

The relationship between Brill's considerate war and the family skirmishes of his past keep the story inside an insignificantly fascinating mental domain. As the longtime editor of the Boston Globe, August Brill writes more than 1500 essays. He now believes that the early writings of himself are to be the "Ephemera". He considers the memoir about him and his abandoned family. He writes a memoir for his family but now he is no more a writer. He reveals to himself stories in obscurity to abstain from considering the women with whom he lived, his daughter grieving over a broken marriage, and his mourning granddaughter. The novel is a narration of sleepless nights and experiences of the insomnia of the protagonist. Brill says, "They might not add up too much, but as long as I'm inside them, they prevent me from thinking about the things I would prefer to forget" (02). He wanted to forget the sorrowful realities of the past. The retired book critic envisions a parallel world where America is not at war with Iraq yet with itself.

Brick is an otherwise appealing and attractive character and also a quiet man. He has a tranquil existence; wedded to a woman named Flora and is tensely anticipating a youngster. At the point when Brick is at last free from the limitation, his leader advises Brick that he is battling a common war in America that has killed the man in charge of the contention. When he challenges, he is educated that he lives in various, parallel universes, a condition hypothesized by a sixteenth-century Italian Philosopher. He looks into the compositions of his rumored unfortunate casualty who is presently uncovered to Brill himself. Brick is soon visited by his tormentors. The two universes impact viciously and he has a short illicit relationship with a woman from his past who has been sent to induce him to acknowledge his main goal. He is eliminated when he refuses to participate in the murder.

However, Brill himself chooses to give the protagonist a chance to die, for all intents and purposes sparing his life and even-mindedly putting a conclusion to the story. Brill executes his dream before the creative mind can suffocate him in the corner of the inkwell, impairing his workforce to recollect the emotional certainties of this present reality.

My subject tonight is war, and now that war has entered this house, I feel I would be insulting Titus and Katya if I softened the blow. [...] Giordano Bruno and the theory of infinite worlds. Provocative stuff, yes, but there are other stones to be unearthed as well. (118-119)

The story inside a story appears to possibly annihilate the storyteller as well. Auster's Protagonist, August Brill, makes a story wherein the fundamental character, Corporal Owen Brick, is allocated the assignment of killing the story's creator at the end of the day, Brill himself. However Brick is reluctant in tolerating his job in the proposed death of Brill. Now and again, he ends up being gone before by Military bosses, who take steps to slaughter him except if he completes his doled out homicide. The long Brick area is separated in style, substance, and feeling from Brill's resulting excruciating recitation. The agonizing quality itself is all of a sudden separated toward the end with the would like to break out similarly as the sun rises.

The theme of identity pervades Auster's writing and his protagonists never stop to scan for intelligence inside them and to bring up supernatural issues: Who am I? Where is the reason for me being here? How would I fit into this world? Is there somebody above who controls my life? All talked about viewpoints lead to a similar end - character is divided, invulnerable, and subtle and liquid in the books of Paul Auster. The parts of the character are to bring to a fantastic end which the heroes bomb as they continued looking for personality. The quest for a way of life just as composing is depicted as an open, progressing and incomplete procedure. Through the novel Man in the Dark, he returns to some of the themes evident in his previous novels such as loneliness, self-identity and the fluid identity. In the end, the narrative involves innumerable ordinary people's existence.

The novel Man in the Dark begins ominously: "I am alone in the dark, turning the world around in my head as I struggle through another white night in the great American wilderness" (Man in the Dark 01). The protagonist is obsessed with the desperation by a collection of personal sorrows. To divert his mind, he imagines a story. 
In that story, he imagined a character named Owen Brick, a children's magician. He is dressed in a soldier's uniform which is made of rough, dull-coloured wool. He wears a cap on his head and a pair of sturdy, well- worn black leather boots on his feet. He is wearing two army stripes on each sleeve of the jacket. It indicates that the uniform belongs to someone with the rank of corporal. "But the man in the hole, whose name is Owen brick, cannot recall having served in an army or fought in a war at any time in his life" (02)

He has temporarily lost his memory. A voice from the top of the hole wakes him up the next morning. A man helps him to come up. He did not realize who he is. He has introduced himself as Serge Tobak, his sergeant. Brick looks at the man and repeats the name in a low voice. He asked him "What am I doing here?" He cannot get his past memory. Serge tells him that he is fighting a war. But he did not know about the war. He thought that he was in Iraq. Serge tells him that "This is America and America is fighting with America (8). Brick does not know what he is talking about. His Commanding Officer advises Brick that he is battling in a common war in America and that he has been chosen to murder the man in charge of the contention.

In Auster's story within a story, the protagonist's search for identity is well described in the novel with the character of Brick. He is in a confused state without the awareness of who he is and what he is doing there in a hole. He asks a sequence of questions to the unfamiliar man Serge. Like the characters in most of Auster's novels, the figures in these books are confronted with absence and gaps, in which they are searching for the true self. Accordingly, he writes about his personal self and uses his writings as an expression of his quest for identity within Native America's prevailing conditions that nourishes and sustains his writing. Thus, not only the protagonist but also the other characters of the novel yearn to escape from the real-life traumas that in turn have gifted them with a nonstatic identity and spend their time in finding out an outlet to get rid of it. They feel frustrated with the past experiences of death and memory. The changing identity and loss of memory of the protagonist alone remain static.

\section{REFERENCES}

1. Auster P., Man in the Dark, Faber and Faber Limited, Bloomsbury House: London. 2008.

2. Ashcroft, Brill. et al. Rerouting the Postcolonial: New Directions for the New Millennium. Oxon: Rout ledge, 2010.

3. Auster P., Leviathan, Viking Press: New York.

4. Balaev M., The Nature of Trauma in American Novels. Evanston: north Western University Press. 2012.

5. Book reviews: Man in the Dark and Supreme Courtship<https://www.nytimes.com/2008/08/28/arts/28ihtbookthu.1.15673979.html>

6. Paul Auster Man in the Dark <http://www.greatbooksguide.com/austermaninthedark.html>

7. The Insistent Realism of Don DeLillo's 'Falling Ma' and... Academia.edu

<http://www.academia.edu/1371976/_The_insistent_realism_of_Don_ DeLillos_Falling_Manand_Paul_Austers_Man_in_the_Dark>

8. Man in the Dark: A Novel - Paul Auster - Google Книги <https://books.google.ru/books?id=J218aP20KA0C\&hl=ru>
9. Psychological trauma <https://en.wikipedia.org/wiki/Psychological_trauma>
Wikipedia
10. Contemporary American trauma narratives... - Terkko Navigator <https://www.terkko.helsinki.fi/contemporary-american-trauma- narratives>
11. Man in the Dark by Paul Auster - PopMatters <https://www.popmatters.com/man-in-the-dark-by-paul-auster- 2496132273.html>

\section{AUTHORS PROFILE}

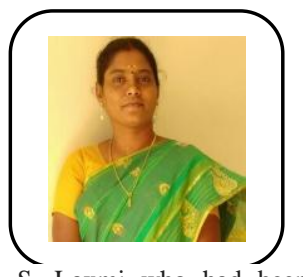

Dr. C. Jothi, M.A., M.Phi.,1 Ph.D. was the former head of the Dept. of English,Kalasalingam Academy of Research and Education, Deemed to be University, Krishnankoil, Tamilnadu. Presently she is serving as Assistant Professor-II for the same University .Graduating from M.V.M Govt. Arts College, Dindigul, she did her Ph.D. in Gandhigram University under the guidance of Dr. S. Laxmi who had been instrumental and inspirational for her research accomplishments on the Brazilian writer, Paulo Coelho. She has presented and published many articles in literature, has attended many Workshops and Training Programmes to her credit During her tenure as a Head, she had organized two 3 Day Faculty Development Programmes, 18 Guest Lectures, Employability Training Programmes for students and a Workshop on Relax and Unroll for faculty.. As an ardent reader and meticulous mentor, Dr. C. Jothi has to her credit been fervently teaching literature and criticism and guiding many aspirant scholars in their pursuit of knowledge. She has published a book entitled Mystical Quest in the Novels of Paulo Coelho. Besides, she is an active member of ELT@I. 